\title{
Specifics of Artistic Culture of the Krasnoyarsk Territory (Krai) Based on Artwork Analysis
}

\author{
Yuliya N. Avdeeva, Kseniya A. Degtyarenko \\ and Anna A. Shpak* \\ Siberian Federal University \\ 79 Svobodny, Krasnoyarsk, 660041, Russia
}

Received 14.07.2017, received in revised form 11.08.2017, accepted 22.08.2017

The purpose of the present research is to explore regional architectural peculiarities in order to determine cultural and historical value of certain pieces of architecture in the regions. Philosophic and artistic review of the Zuckerman house in the city of Krasnoyarsk reveals the way local culture preserves historically developed individual images and the way it transforms under the global cultural influence. First of all, this fact satisfies the tasks of the current cultural policy connected with the preservation of cultural heritage, and, on the other hand, it reflects the changing needs and lifestyle of the urban society. It proves that regional architecture is not isolated from the outer world; it accepts new stylistic trends actual for the urban and sociocultural space. The novelty of the research lies in the introduction of empirical data on artistic and aesthetic qualities of historical and cultural value of some public architecture objects from the periphery into a scientific context. Regional objects of cultural heritage may represent local artistic and sociocultural phenomena as well as the all-Russian and universal ones.

Keywords: regionalism in architecture, regional identity, contextualism, urban society, aesthetic portrait of the city, city of Krasnoyarsk, the Zuckerman house, "Genius loci".

The reported study was funded by Krasnoyarsk Regional Science and Technology Support Fund within the framework of "Decorative and applied art of indigenous peoples of the Krasnoyarsk Territory: current status, prospects for development" project.

DOI: 10.17516/1997-1370-0137.

Research area: culturology.

\section{Introduction}

With the accelerating growth of development and spreading innovative technologies, more and more attention is paid to the uniqueness of some certain areas, originality of the regions. Regional identity may be expressed, for instance, in some pieces of architecture. Reflection of regional uniqueness in architecture was first noticed at the turn of the $19^{\text {th }}-20^{\text {th }}$ centuries (NorbertSchulz, 2004), when Art Nouveau style was "invading" the area, though some national styles were revived. In the early $20^{\text {th }}$ century, local

(c) Siberian Federal University. All rights reserved

* Corresponding author E-mail address: yulia-avdeeva2406@mail.ru; akseniya.krupkina@mail.ru; annaheyy@gmail.com 
Krasnoyarsk architects, such as V.A. Sokolovsky and his mansion projects, introduced the "new style" into the community's everyday life. One of these projects is the known Zuckerman house (currently, the building of the Literature Museum named after V.P. Astafiev).

\section{Methodology}

The present research is based on the comparative analysis method as well as philosophical and artistic review method developed by V.I. Zhukovskiy (2004, 2007), N.P. Koptseva (2004，2007，2015), and K.V. Reznikova (2015) for the detection of general and unique characteristics in local regional architecture.

\section{Literature review}

The up-to-date problems of interaction between architecture and the surrounding medium, society and personality are studied in multiple works by modern researchers. Studying architectural pieces from the point of view of perception is associated with the term of visual thinking, which reflects the process of interaction with art. Such authors as R. Arnheim (2000), A. Binet (1894), S. Freud (2016), B.F. Skinner (1957) and others assign the major role in interaction with art, and architecture in particular, to perception, thinking and visual image.

Communicative capacity of art, principles and peculiarities of such communication have been researched by the following authors: H.G. Gadamer （1991), H. Sedlmayr (1999), M. Heidegger (1993, 1989), Iu.M. Lotman (1994), S. Lagner (2000), A.F. Eremeeva (1987), M.M. Bakhtin (1987) and others.

In the $20^{\text {th }}$ century, at the intersection of art criticism and cultural studies a new branch of visual anthropology appears, to study pieces of art in the aspect of social values' representation. The first place in the social values representation system is undoubtedly occupied by architecture (Bukova, 2014; Kolesnik, 2016; Seredkina, 2016; Sitnikova, 2014; Sitnikova, 2015). As such representatives, pieces of art are studied in the context of urban science (Sertakova, Gerasimova, 2015).

M.S. Tarasova studied urban architecture of Krasnoyarsk as an intermediary between person and society, a connecting link able to recreate well-balanced co-existence, unity of human and nature, as well as the space of people's selfidentification, understanding their place in the world (2015). A special role in the development of Krasnoyarsk urban space is played by its "heroes", the main of which in the world of art is Vasily Ivanovich Surikov (Kistova et al., 2016).

In her studies, N.N. Pimenova also turns to wooden architecture of Krasnoyarsk as a means of forming personal self-identification, inter alia, in the social and ethnic aspect (2015). Sociocultural researches of the urban space have been also carried out by E.A. Sertakova and N.P. Koptseva (2015).

"Krasnoyarsk architecture of the $19^{\text {th }}$ -early $20^{\text {th }}$ centuries. Stylistic peculiarities" by M.E. Merkulova is dedicated to the study of architectural heritage, history, and search for the general tendencies in Russian architecture development (2005). Issues of development from the $17^{\text {th }}$ to the $20^{\text {th }}$ centuries, as well as historical and archive data, biographies of the architects are presented in works by A.V. Slabukha (2004).

Siberian wooden architecture of the late $19^{\text {th }}$ early $20^{\text {th }}$ centuries was studied by V. Cherepanov (1986). Some buildings of the same period were also analyzed by V.I. Tsariov, V.I. Krushlinskiy, including analysis in the aspect of architectural environment development (2001). The specificity of the stylistic forms of the Krasnoyarsk architecture of the early $20^{\text {th }}$ century including the Zuckerman house was the object of research by Iu.I. Grinberg and I.L. Rodnianskaia (1989). 
A brief description of the Zuckerman house can be found in an article by E.Z. Goncharova (2015). Articles by K.Iu. Shumov draw attention to the history and reconstruction of the architecture of Krasnoyarsk and the Krasnoyarsk Territory (Krai) (2002).

\section{Regional architecture}

As a term, regionalism (from Latin regionalis: local, provincial) is defined as a form of identification with a certain territorial area, manifesting itself through ideas, activity and products of activity, intended to preserve and determine cultural originality of a region. The term may be also applied to the $20^{\text {th }}$ century architecture, which typically "turns to the traditions of local (ancient or folk) architecture and strives to use local natural and climatic conditions in the most efficient way" (1973).

Architecture determines the aesthetic portrait of a city, reflecting the history of styles of all historical periods. A piece of architecture is a child of its age with its aesthetic needs and tastes, ideas and lifestyle of the urban community. A piece of architecture demanded by the society is a result of both design and construction of modern buildings, as well as of reconstruction of the existing architectural objects. Therefore, the aesthetic portrait of a city is a dynamic phenomenon which constantly transforms and completes itself under the influence of politics, economy, and ideology.

Currently there are two main trends in the world architecture: regional and global. Speaking of regionalism, it is worth mentioning that modern architecture of certain regions develops not only under the influence of its traditional forms, but also as a result of interaction between cultures and various stylistic trends. In modern architecture, regionalism manifests itself in such stylistic trend as contextualism, which also turns to some individual images of the regional motives and is oriented toward local culture. This trend was developed, to some extent, through the attempts to revive and adapt some old pieces of architecture for new purposes. For contextualism, it is typical to turn to the past experience, use some fragments of historical architecture, reproduce its general "key", i.e. to indorse the object of architecture into the historically developed environment as much as possible.

Turning to regionalism, some modern architects stick to the "genius loci" concept (spirit of the place). For the first time, the term was introduced and popularized by the Norwegian architect Christian Norberg Schultz (2004). The "genius loci" motive is especially topical in the context of development of the regions with a historically developed appearance, serving as an important designing tool. Any architectural object should be perceived where it is and how it matches the surroundings in the way that makes it impossible to imagine it in a different place. Only in this situation architecture can be harmonically combined with the environment. "Genius loci" may be both an existing or acquired category. Modern experts (2014) list the following universal criteria for the genius loci detection:

1) history of the region;

2) terrain and nature conditions. Possibility of using local construction materials;

3) tools of construction and volume configuration;

4) traditions of the design area.

Regional way of development does not mean isolation from the surrounding world. Regionalism helps revealing local originality, at the same time, under the influence of global culture. This architecture is often eclectic, born in the interaction of styles, succession and connection to tradition.

An example of such eclectic architecture of Krasnoyarsk are the mansions created by 
V.A. Sokolovsky in the early $20^{\text {th }}$ century, presenting the architectural style of the new era, harmonically intertwined with some exquisite historical shapes. It is impossible to take your eyes off the mansions by Sokolovsky. The intensiveness of complementary decorative elements, delicate carved details attract and tempt the viewer with their fairy-tale character and unusualness to take a closer look.

This is what Sevastyanov estate, the corner building at the junction of Gorky and Karl Marx streets is like (Fig.1). It was reconstructed by V.A. Sokolovsky in 1908. During the works, the second floor was built, changing the appearance of the building and bringing it to the condition we know today. The mansion of merchant Sevastyanov is one of the regional objects of cultural heritage with rich and plastic architectural elements. The originality of decorations, tent-roofed turrets with spires, bear the tendencies of the new age, determining the architectural specificity of the region, can be also found in other buildings of Krasnoyarsk, such as the Zuckerman house we will analyze below.
The Kozlovskaya estate (Fig. 2) located in Dzerzhinskogo St., combines the traditional structure of a $19^{\text {th }}$ century urban house with some Art Nouveau elements in its decorations. It is a two-storey log house with a rectangular foundation and a hipped roof. At the end wall of the main seven-axis façade, there is a protruding uniaxial avant-corps crowned with a gable with a carved tympanum decorated with a small arch, over which there is a tetrahedral tent with a spire and some ornamental metal elements. The grand entrance in the avant-corps has a massive roof overhang resting on heavy carriers. The groovy pilasters are similar on all the three facades of the building. Some features of Art Nouveau are found in the carving of the window trims and the entrance console, as well as in the floral pattern on the front door.

The internal longitudinal wall divides the house into two parts, the front and the back. Some dog-legged stairs side with the north end of the wall.

The Zuckerman house (Fig. 3) was built in the late $19^{\text {th }}$ century and renovated by Sokolovsky in the year 1911. Being an example of the typical

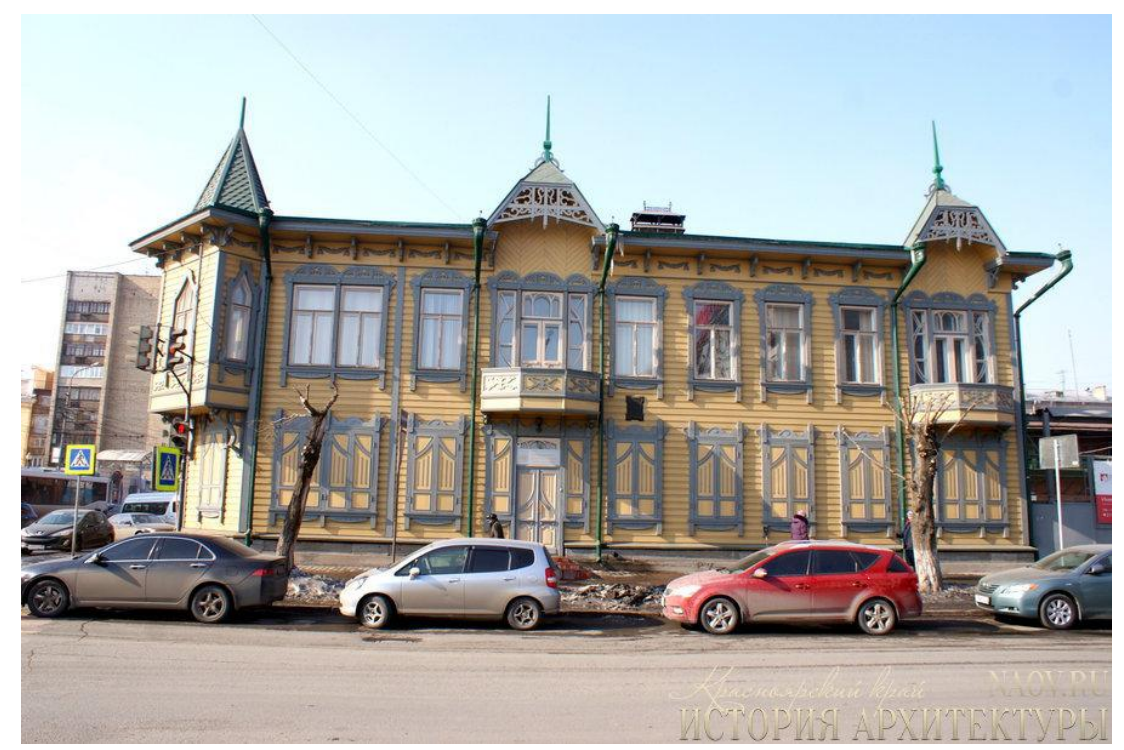

Fig. 1. Mansion of merchant Sevastyanov ${ }^{1}$ 


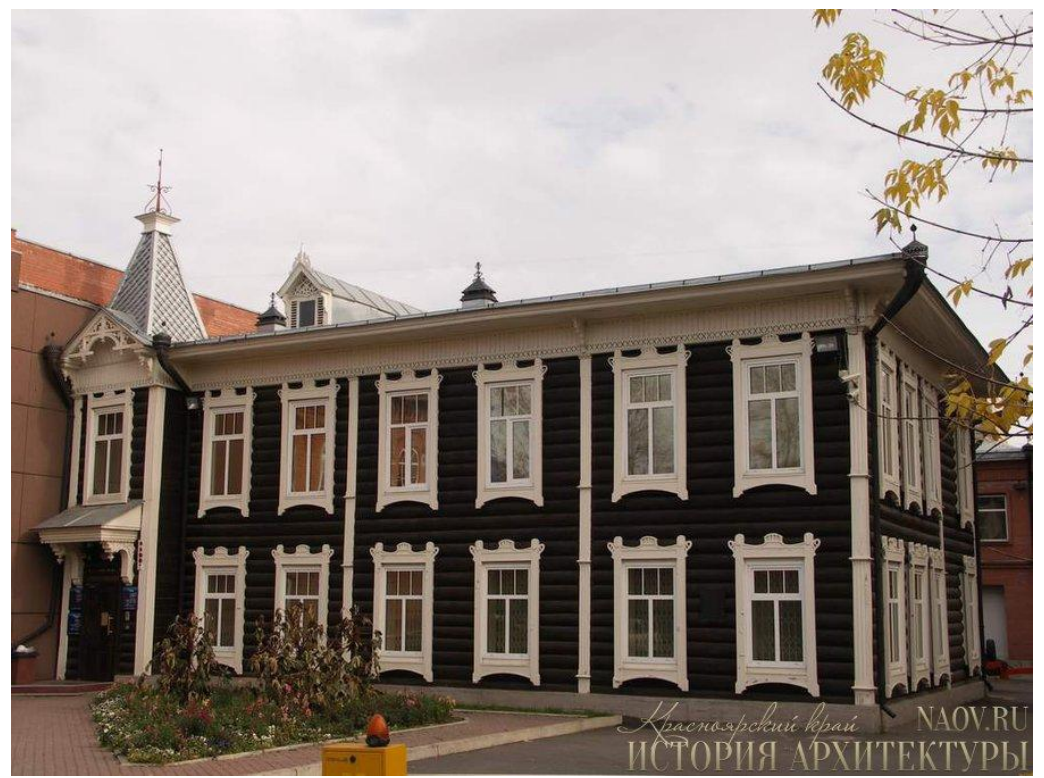

Fig. 2. The Kozlovskaya mansion ${ }^{2}$

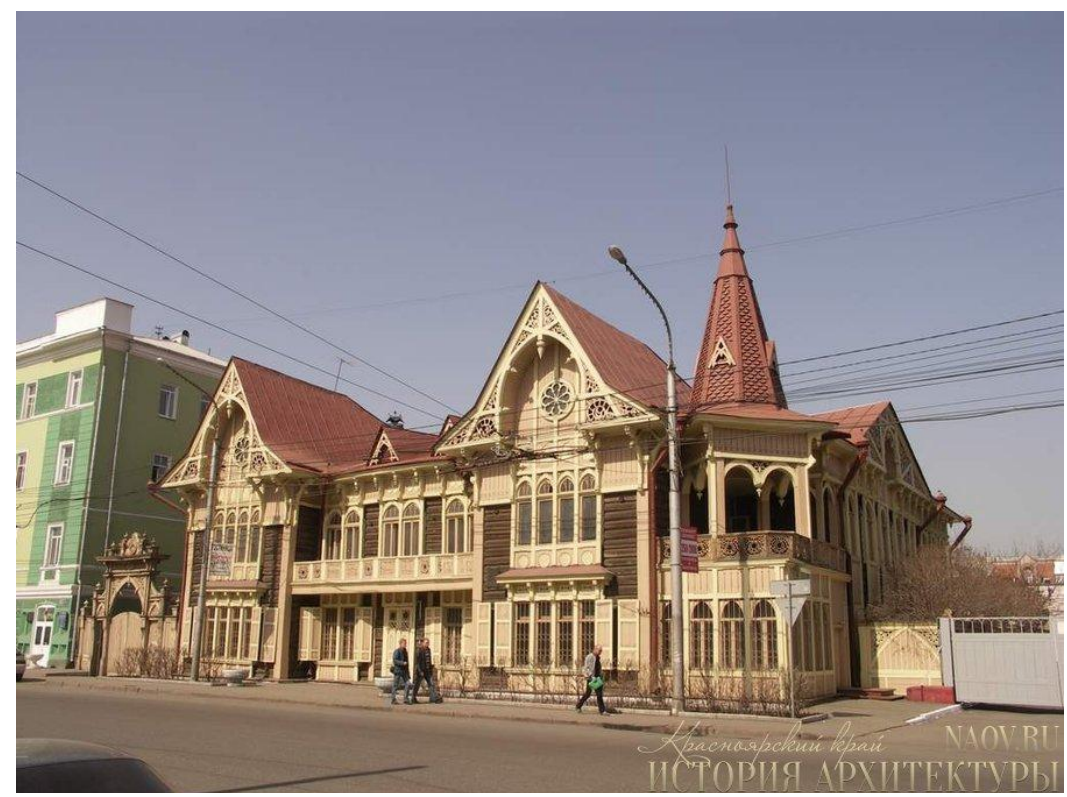

Fig. 3. The Zuckerman house ${ }^{3}$

eclectics of the turn of centuries, it is a picture of its time as the age of innovations. The building combines various styles and architectural trends. Let us take a closer look at it. In the Zuckerman house, we can find the features of the following styles: Art Nouveau, Eclectic, Flamboyant, as well as strong influence of typical Russian wooden architecture. Being a popular trend both in Russia and abroad, in the late $19^{\text {th }}$ early $20^{\text {th }}$ century Art Nouveau encompassed some of the preceding trends, such as Gothic Revival, Eclectic, brick style buildings. Eclectic allowed making free layouts of houses and apply asymmetric solutions to the compositions. One 
of the brightest representatives of the epoch is a piece of Northern Art Nouveau, the mansion of Maria Eduardovna Kleinmichel (Fig. 4) built in Art Nouveau style with some Gothic Revival elements. In the exterior, we may find lots of similarities with the Zuckerman house: the protruding avants-corps, a square gallery, as well as floral and zoological motives in the façade and decorative ironwork.

Such piece of Gothic Revival architecture as Novopetergofsky railway station (Fig. 5) allows us to compare some of the decorative elements. As a piece of Gothic Revival, the Zuckerman house has some lock arched windows, bulbous and spired domes. Round Gothic stained-glass windows, four-leaved decorations.

Based on the example of a Russian style building (Fig. 6) we may study some peculiarities of traditional Russian architecture, and tower building in particular.

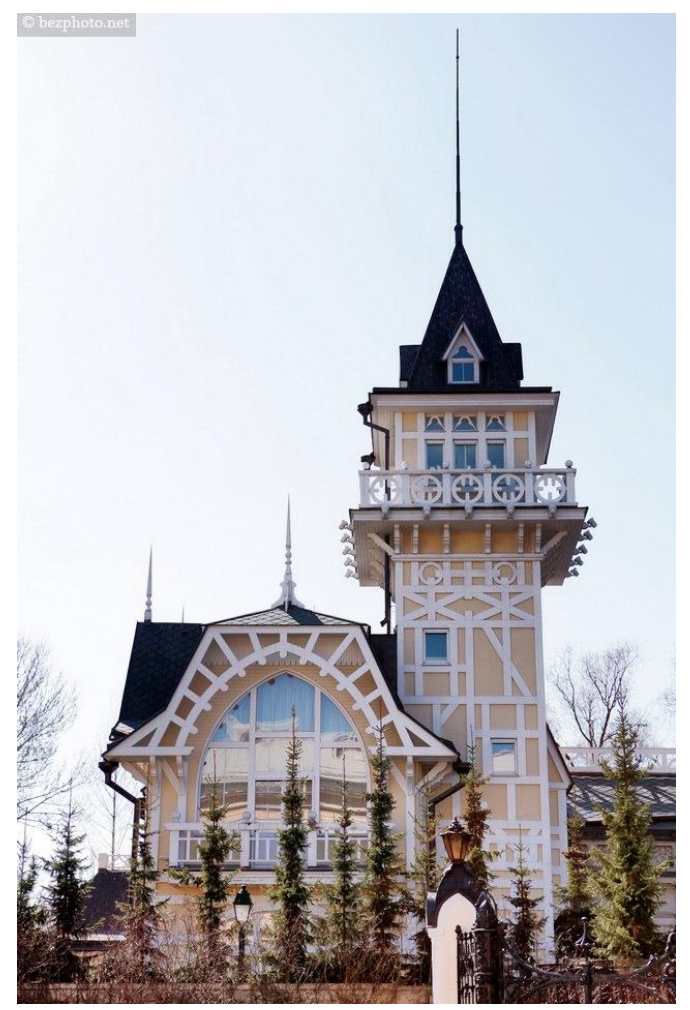

Fig. 4. Mansion of M.E. Kleinmichel ${ }^{4}$

\section{Philosophic and artistic analysis of the Zuckerman house}

The Zuckerman house is a survived element of a large merchant estate reconstructed in the year 1911. Besides the house, the premises included a two-storey stone house with iron roof, two wooden outhouses, a stable, a barn, a two-storey stone farmery (2014). The house is located in Lenin Street, in the historical centre of Krasnoyarsk.

The central façade overlooks Lenin Street; it is symmetric. The building used to be surrounded with a fence with an entrance gate, but due to the high density of the modern city the fence remains only on the central façade side in Lenin Street. The wooden fence had a floral ornament in the year 1913 (Fig. 7), interrupted with the central façade and then the gate. Today, the fence is interrupted with the modern buildings, but the entrance gate still exists.

The wooden minter gate (Fig. 8) has chiselled decorative elements, and on the sides from the gate there are two galleries; the whole face of the gate is richly decorated with a natural ornament. Over the gallery entrance doors, there is a trefoil, a Christian symbol for the Holy Trinity. The gate is divided into straight horizontals with mouldings and crowned with some bulbous elements. The floral ornament is interpreted in the Ancient Russian symbolism; it represents a solar sign, an averter (Ladinets symbol or Virgin Lada's Cross is a very ancient Slavic Vedic solar symbol believed to bring family happiness, love and harmony). Despite the clear horizontal division, a vertical one is seen in the columns and the gate lined with parallel vertical wooden elements equally apart from each other. The vertical division of the gate dominates of the vertical, which symbolizes outward motion.

Let us take a look at the peculiarities of the central façade. As it has been mentioned above, it is quite symmetric; on the sides from the central 


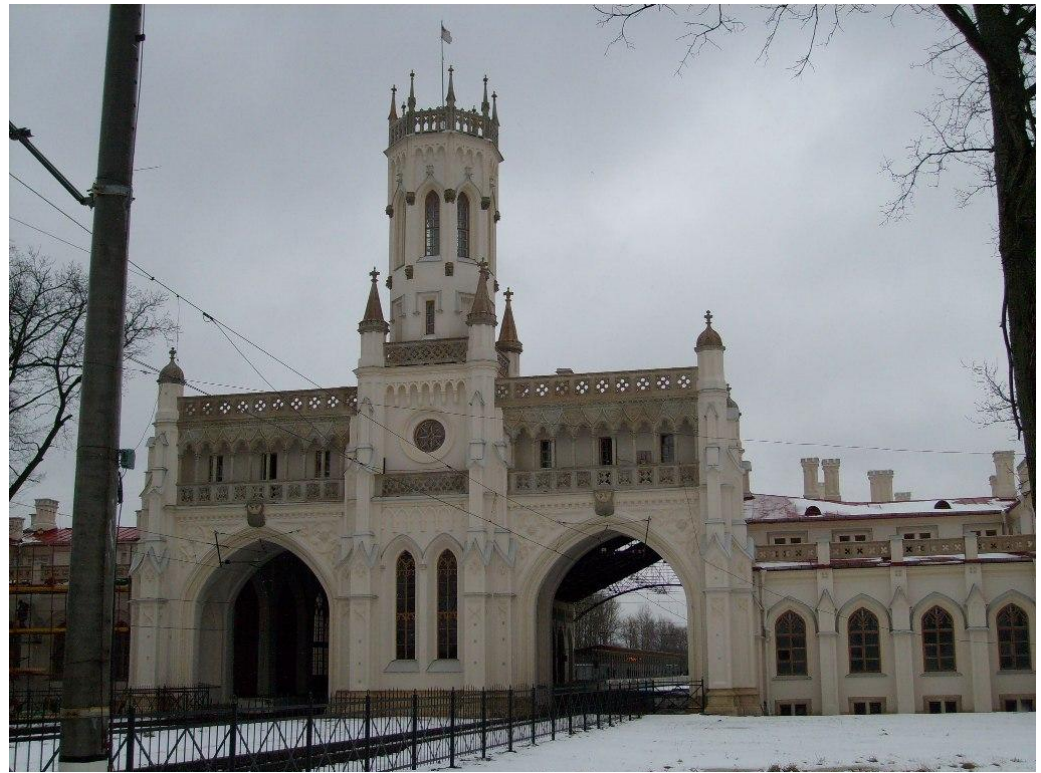

Fig. 5. Novopetergofsky railway station. Photo by Sasha Krotov

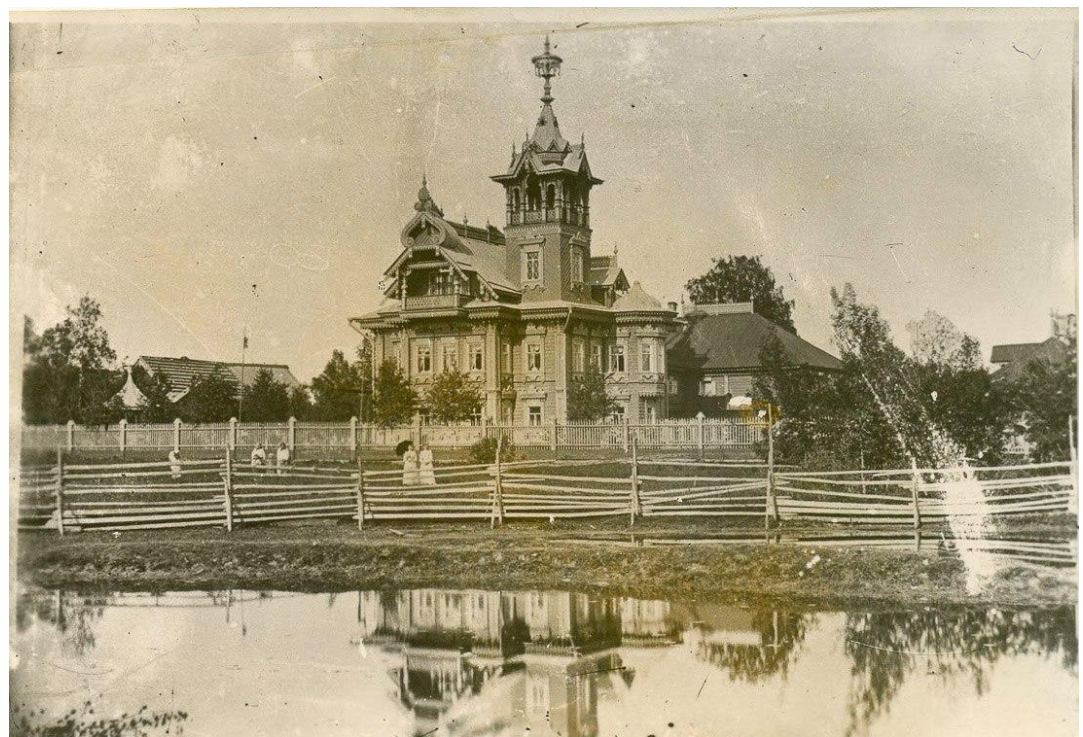

Fig. 6. Tower by Ivan Ropet. Astashevo

axis, there are two avants-corps marked with the tall protruding pediments decorated with a natural ornament and some round windows reminding of the Gothic style. The central entrance is the symmetry axis of the façade. It has heavy minter doors repeating the trefoil ornament previously found over the entrance gate. Remarkably, this ornament is repeated all over the façade.
The house has multiple tall arched windows, creating the illusion of the vertical orientedness of the building (Fig. 9) (2009). On the façade, the windows are cut in groups; each avantcorps unites four windows in the central façade into two groups. On all the facades, the lower floor windows are rectangular. The detail that hits the eye is that all the pediments are similar 


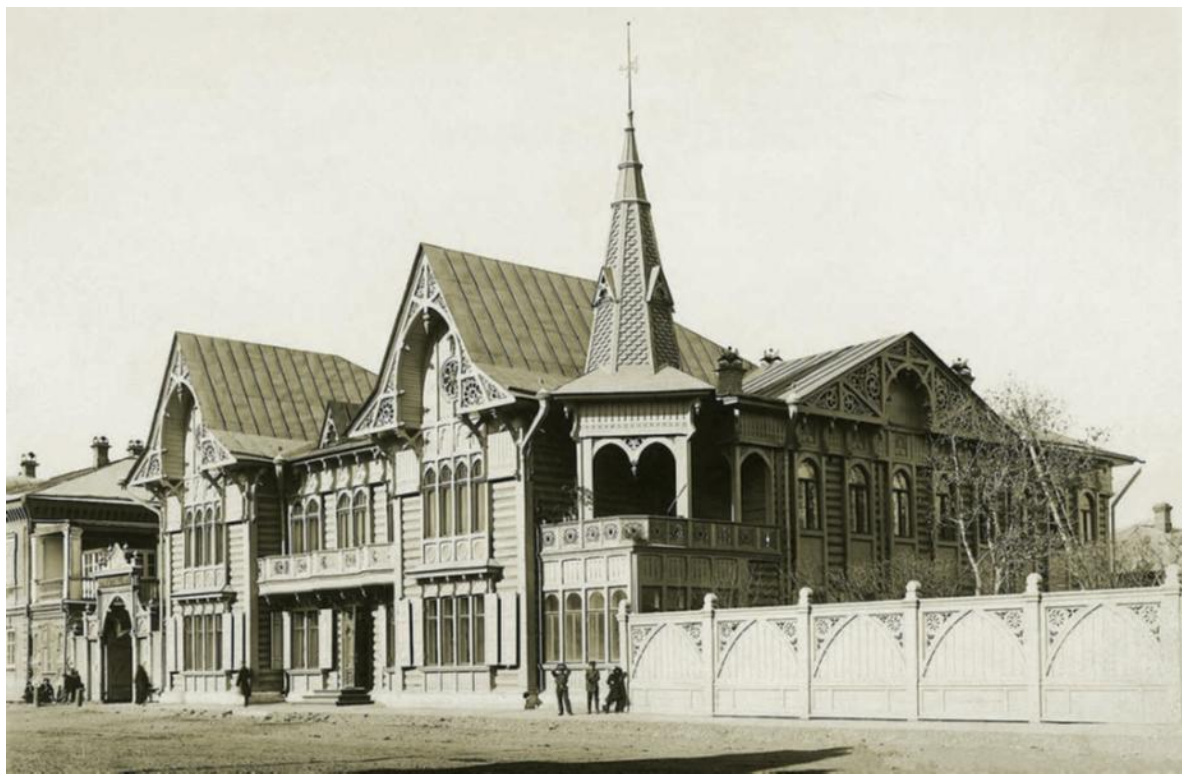

Fig. 7. The Zuckerman estate after reconstruction by A. Sokolovsky, 19116

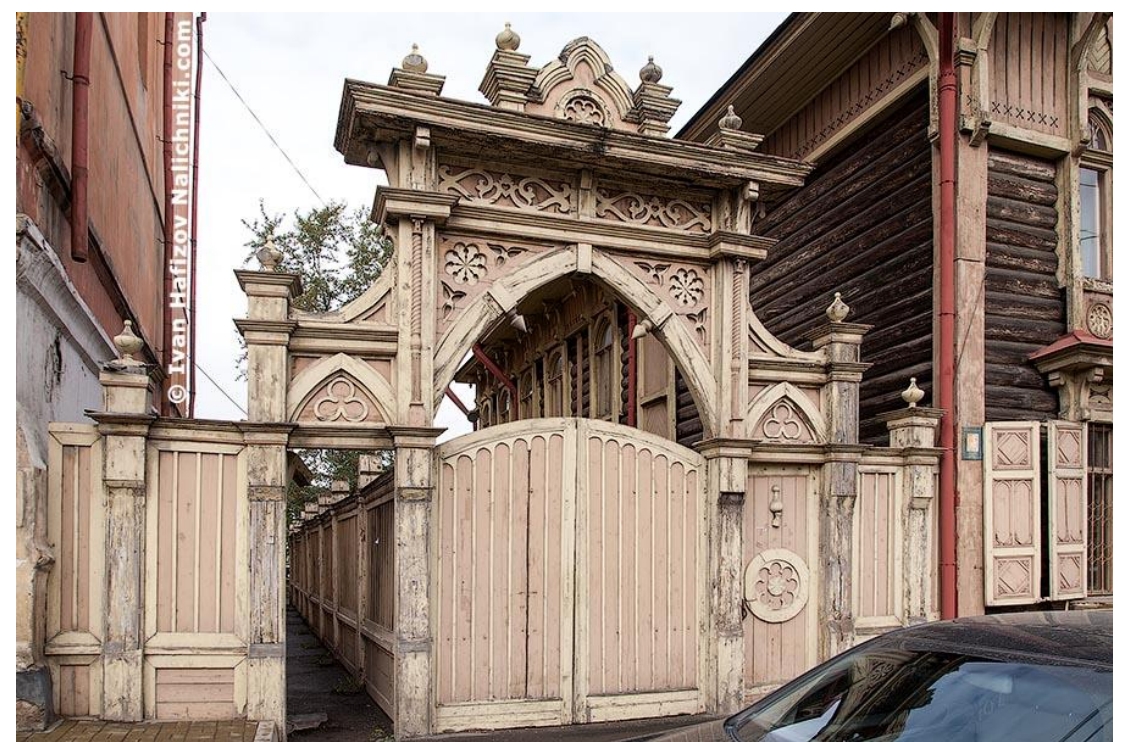

Fig. 8. Gate of the Zuckerman house. Photo by Ivan Hafizov

in decorations and the windows are equally apart from each other. The length of the streetoverlooking façade is 26 metres; for the western it is 21 metres and for the eastern it is 25 metres.

The gallery breaking the symmetry on the right brings more dynamics to the piece. The lower part of the gallery remains closed, it is glass-sided and boarded. The upper part lays on a cubic foundation, four squares in the base of the pillar. As for the lower part, this volume lays across the lower base. It is necessary to remark that the upper part of the gallery is through and framed with carved ornament. The gallery roof has four facets, as well as a hexagonal tent roof with a spire covered with red scale tiles. The logs of the house are decorated with pilasters. 


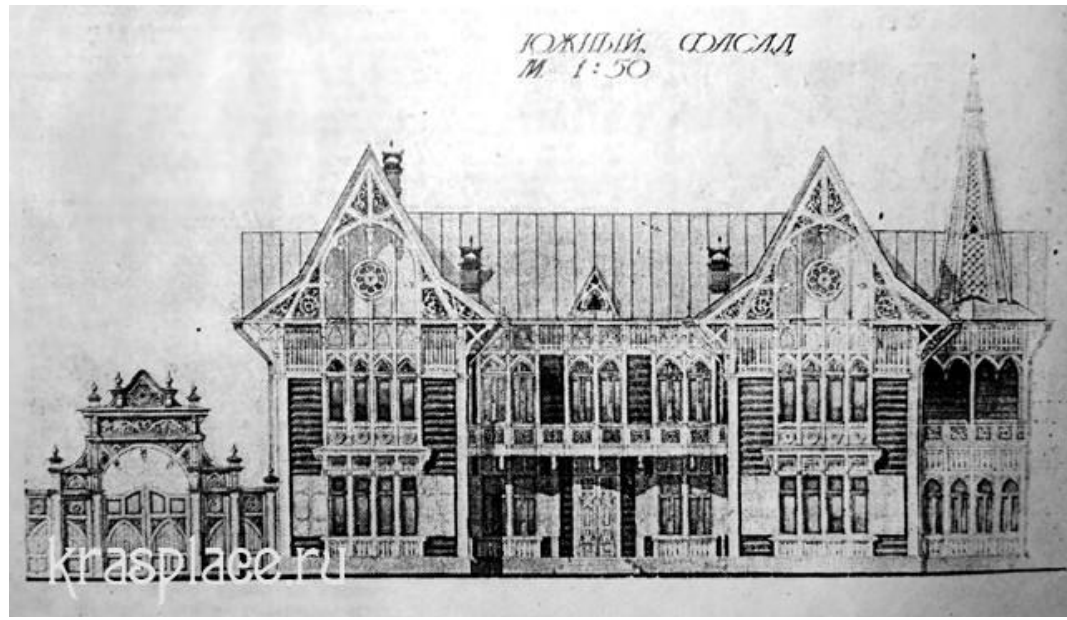

Fig. 9. Façade project ${ }^{7}$

The principal shape of the building is almost a cube. The pedestal of the building is made of brick, though the rest of the two-storey house is wooden. The roof is multileveled. The cubic volume is hardly visible in the layout due to the multiple crossing and transforming lines; it is broken with the sophisticated rhythm of architecture.

The next stage of the research is the description of the interior of the Zuckerman house. According to the layout, the entrance section is rectangular; the front enfilades in the entrance part of the house create a through view
(Fig. 10, Fig. 11). This part of the house contains some grand halls and study rooms.

The grand staircase is seen from the central, multifaceted hall (Fig. 12), which may refer to the Art Nouveau influence on the interior. The lobbies have large doors decorated with a natural ornament. The grant staircase always acts as a communicative element; due to the interinfluence of styles, Art Nouveau does not have any sharp edges. On the opposite, the plains look smooth, framed with the decorative railing with carved quadrifoils.

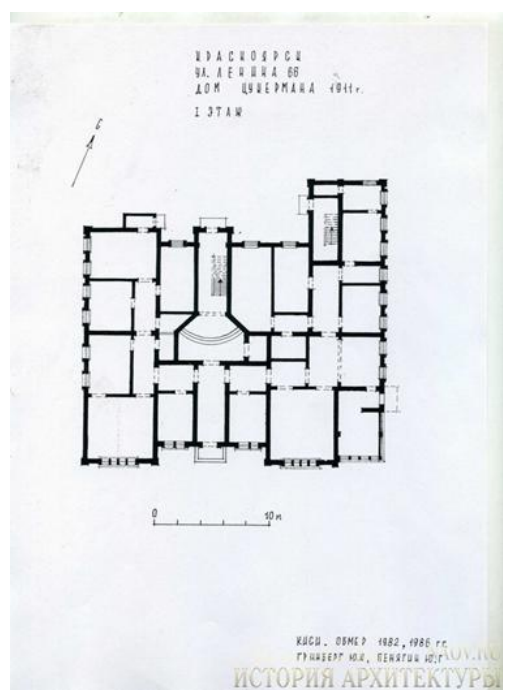

Fig. 10. 1st floor layout ${ }^{8}$

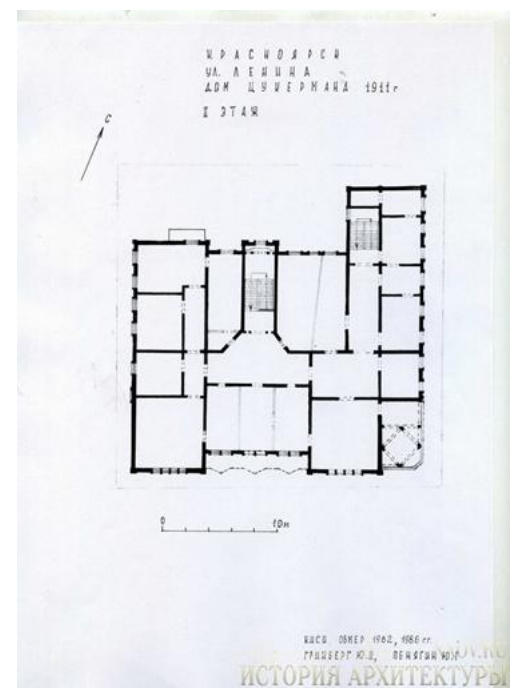

Fig. 11. 2nd floor layout ${ }^{9}$ 


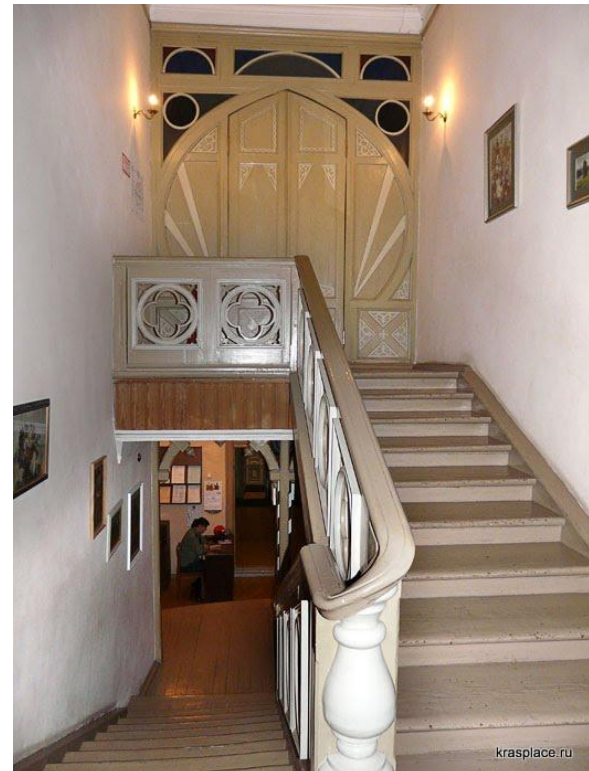

Fig. 12. Grand staircase ${ }^{10}$

The peculiar aspect of Art Nouveau style in this piece is the correspondence of the interior to the external appearance of the building. A stained-glass lancet window overlooks the staircase, being a Gothic element in the interior. As for the side parts of the premises, they include residential apartments and service facilities. The house also holds such elements as screens that separate a space with benches near the stainedglass lancet window in the staircase zone (Fig. 13). The carved doors and such decorative elements as quirks, rosaces, and carving survived through the time.

Though the furniture of the interior is not original, it is selected in accordance with the style. The chandeliers and bracket lamps also correspond to the period of construction.

Architecture interacts with the viewer both by means of interior and exterior. Communication between the piece of architecture and the person begins, when the he discovers the appearance of the building. This mansion is located in such a way that it is accessible through different ways.

First of all, it is possible to enter from the south-east side of the building; then the first

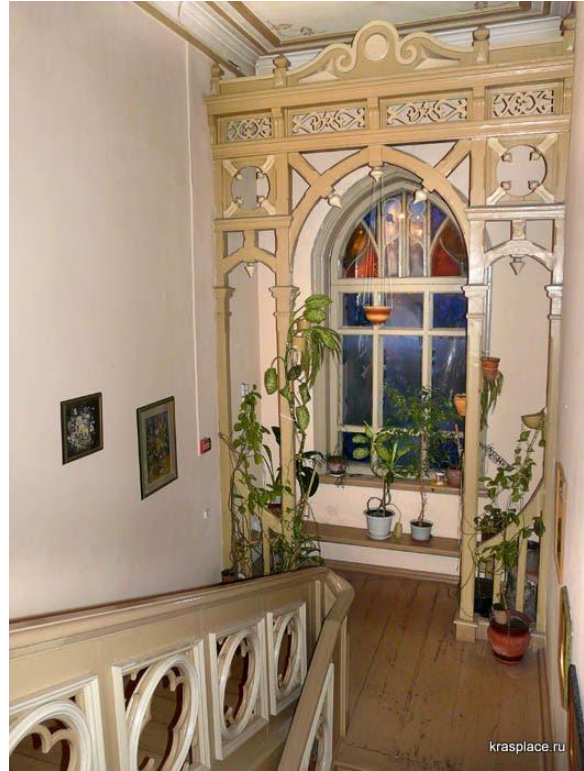

Fig. 13. Stained-glass lancet window ${ }^{11}$

thing that hits the eye is the gallery. It attracts the viewer with its non-standard location and solution, domination of vertical shapes with a light ornament that tempts the visitor to look up.

Secondly, approaching the building from its south-western side, the viewer faces the gate. Like the gallery, they have dominating vertical orientation. Despite the difference in the first external impression, it enhances closer to the main façade. It is maximally vertical due to the avants-corps, upstretched pediments and rhythmically located arch-like window apertures.

Thirdly, studying the communication of the viewer with the building exterior, it should be noted that the first room he enters is the lobby. The first thing he pays his attention to is the enfilade and the grand staircase. The smooth volumes of the staircase, the screen and the stained-glass lancet window tune the viewer to trusting attitude. In the area, he feels freedom of movement; he may visit the halls and studies of the literature museum.

As the mansion has multiple halls and reception rooms, the literature museum enters the urban medium as an enlightening and educating 
component of local life. Various literature conferences and disputes let the visitor enter the world of literature or take part in solving social issues. Looking at the museum from the exposition point of view, we see that it does not provide a logical order of walkthrough, therefore, letting the audience study the exhibits in a random order.

So, the communication between the viewer and the studied piece of architecture bears enthusiastic character, it opens the way to mystery, gradual plunge into the sophisticated architectural forms and decorations, lets the person escape from the everyday reality, relax the mind, and, relieved of the mundane burden, touch the Beauty as it is.

\section{Conclusions}

The comparative analysis has demonstrated how, being representative of the Eclectic Art
Nouveau, some Krasnoyarsk objects of cultural heritage may reflect both the tendencies of the $19^{\text {th }}-20^{\text {th }}$ century's Russian architecture in its regional aspect, and the historically developed phenomena of Russian and universal architecture and culture (Art Nouveau, Eclectic, Gothic, Russian styles), retaining, at the same time, its regional identity.

The philosophic and artistic analysis of the Zuckerman house revealed how a piece of architecture fits the surrounding environment, how it may influence the local society, satisfying its cultural and spiritual needs. The object of architecture begins its contact with the viewer by attracting him with its original appearance, tempting the onlooker to take a closer look at its architectural forms and to enter the house, where he may find the opportunity to communicated with the world and his own self through the works of art.

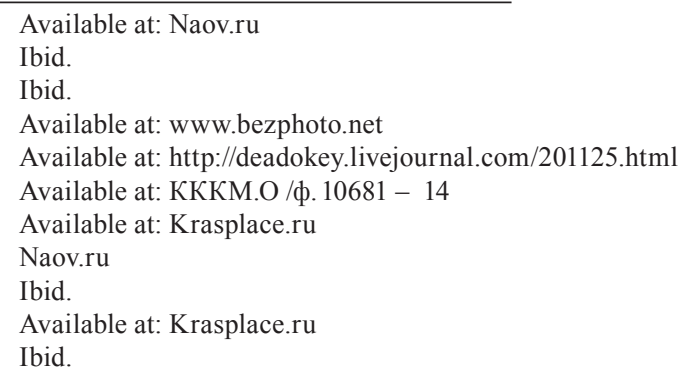

\section{References}

Arnkheym, R. (2000). Iskusstvo i vizual'noe vospriiatie [Art and visual perception]. Blagoveschensk.

Bakhtin, M.M. (1979). Estetika slovesnogo [Aesthetics of the Verbal]. Moscow, Iskusstvo. 424 p. Binet, A. (1894). Mekhanizmy myshleniia [Thinking mechanisms]. Odessa.

Bukova, M.I. (2014). Nekotorye aspekty teorii sotsial'nykh tsennostey [Some aspects of social values theory], In Sotsiodinamika [Sociodynamics], 12, 78-89. DOI: 10.7256/2409-7144.2014.12.1390. Available at: http://e-notabene.ru/pr/article_13901.htm

Cherepanov, V. (1986). Dereviannoe kruzhevo Krasnoiar'ia [Wooden filigree of Krasnoyarsk]. Krasnoyarsk. P. 160.

Dom kuptsa Tsukerman [The Zuckerman house]. History of architecture of the Krasnoyarsk Territory (Krai). Available at: http://new.naov.ru/?pamjatniki_arhitekturi_krasnojarska\&id=1506.

Dom Tsukerman [The Zuckerman house], In Krasnoe mesto, 28.11.2009. Available at: http:// www.krasplace.ru/dom-cukerman. 
Eremeev, A.F. (1987). Granitsy iskusstva [Borders of art]. Moscow, Iskusstvo, P. 317.

Freud, Sigmund (2016). Psikhoanaliz tvorchestva [Psychoanalysis of creativity]. Moscow, Algoritm, P. 254.

Gadamer, G.G. (1991). Aktual'nost' prekrasnogo [Actuality of the beauty]. Moscow, Iskusstvo.

Goncharova, E.Z. (2015). Arkhitektura kak vizual'nyy istochnik v issledovanii gorodskikh soobschestv Sibiri (na osnove zhilykh domov evreev-predprinimateley g.Krasnoiarska na rubezhe XIX-XX vv.) [Architecture as a visual resource in the Siberian urban communities' research (based on the residential houses of Jewish entrepreneurs of Krasnoyarsk at the turn of the $19^{\text {th }}-20^{\text {th }}$ centuries)], In Rossiia i ATR [Russia and APR], 1 (87), 162-179.

Grinberg, Iu.I., Rodnianskaia, I.L. (1989). Stilisticheskie osobennosti arkhitektury Krasnoiarska nachala XX veka [Stylistic peculiarities of Krasnoyarsk architecture of the early XX century], In Pamiatniki istorii $i$ kul'tury Krasnoiarskogo kraia [Historical and cultural monuments of the Krasnoyarsk Territory], 374-392.

Heidegger, M. (1989). O suschnosti istiny [On the essence of truth], In Filosofskie nauki [Philosophic sciences], 4, 88-104.

Heidegger, M. (1993). Vremia i bytie [Time and being]. Moscow, Respublika. P. 447.

Krasnoyarsk Regional Museum of Regional Studies.

Kistova, A.V., Moskaliuk, M.V., Sertakova, E.A., Dvoretskaia, A.P. (2016). Ispol'zovanie imeni Vasiliia Ivanovicha Surikova v konstruirovanii polozhitel'nogo obraza goroda Krasnoiarska [Using the name of Vasily Ivanovich Surikov in constructing the positive image of the City of Krasnoyarsk], In NB: Administrativnoe parvo i praktika administrirovaniia [Administrative right and administration practice], 6, 1-13. DOI: 10.7256/2306-9945.2016.6.20967. Available at: http://e-notabene.ru/al/article_20967.html

Kolesnik, M.A. (2016). Osobennosti vospriiatiia russkogo etnosa v molodezhnoy srede goroda Krasnoiarska po rezul'tatam assotsiativnogo eksperimenta so slovom "russkoe" [Peculiarities of the Russian ethnos perception by the Krasnoyarsk youth based on the associative experiment with the word "Russian"], In Sotsiodinamika [Sociodyamics], 4, 59-67. DOI: 10.7256/2409-7144.2016.4.18270. URL: http://e-notabene.ru/pr/article_18270.html

Koptseva, N.P., Reznikova, K.V. (2015). Tri kartini Zdislava Beksinksi: Kak vozmozhno iskusstvo "posle Osventsima" [Three paintings by Zdzisław Beksiński: How is it possible to make art "after Auschwitz"], In Vestnik Tomskogo gosudarstvennogo universiteta [Tomsk State University newsletter], 400, 121-133.

Kurshakova, V.N. (2011). Razvitie kontseptsiy regionalizma $\mathrm{v}$ arkhitekturnom proektirovanii [Development of regionalism concepts in architectural design], In Arkhitekton: izvestiia vuzov [Architecton: Colleges' news], 34.

Langer, S. (2000). Filosofiia v novom kliuche: Issledovanie simvoliki razuma, rituala i iskusstva [Philosophy from the new angle: Research of the symbolism of mind, ritual and art]. Moscow, Respublika. P. 287.

Lotman, Iu.M. i tartuskko-moskovskaia semioticheskaia shkola [Lotman Iu.M. and Tartu-Moscow semiotic school] (1994). Moscow, Iazyki russkoy kul'tury. P. 555.

Merkulova, M.E.(2005). Arkhitektura Krasnoiarska XIX-nachala XXveka. Stilevyekharakteristiki [Krasnoyarsk architecture of the $19^{\text {th }}$-early $20^{\text {th }}$ century. Style characteristics]. Thesis for the academic degree of the Candidate of Art Criticism: 18.00.01. Krasnoyarsk P. 237. 
Norbert-Schulz, C. (2004). Genius loci. Towards a phenomenology of architecture. Edinburgh college of art library. $288 \mathrm{p}$.

Novaia art-kritika na beregakh Eniseiia [New art criticism on the Yenisei banks] (2015). Krasnoyarsk.

Pimenova, N.N., Marysheva, A.V. (2015). Dereviannoe zodchestvo Krasnoiarska kak prostranstvo protsessov territorial'noy i etnokul'turnoy identichnosti [Wooden architecture of Krasnoyarsk as the medium for territorial and ethnocultural identity processes], In Novaia art-kritika na beregakh Eniseiia [New art criticism on the Yenisei banks]. Krasnoyarsk, 221-227.

Reingardt, L. (1973). "Novaia veschestvennost”" i ridzhionalizm. Modernizm [“New corporeality" and regionalism. Modernism]. Moscow, 208-28.

Seredkina, N.N. (2016). Teoreticheskaia model' pozitivnoy etnicheskoy identichnosti i mekhanizmy eio formirovaniia [Theoretic model of positive ethnic identity and mechanisms of its development], In Sotsiodinamika [Sociodynamics], 2, 37-46. DOI: 10.7256/2409-7144.2016.2.17690. Available at: http://e-notabene.ru/pr/article_17690.html

Sedlmayr, H. (1999). Iskusstvo i istina: o teorii i metode istorii iskusstva [Art and truth: on the theory and method of art history]. Moscow, Iskusstvoznanie.

Sertakova, E.A., Gerasimova, A.A. (2015). Obraz goroda Krasnoiarska v ksilografii I problema regional'noy identichnosti [Kranoyarsk city image in xylography and regional identity problem], In Urbanistika [Urban science], 2, 89-99. DOI: 10.7256/2310-8673.2015.2.16355. Available at: http://enotabene.ru/urb/article_16355.html

Sertakova, E.A., Koptseva, N.P. (2015). Sotsiokul'turnoe prostranstvo sovremennogo rossiyskogo goroda (na materiale analiza goroda Krasnoiarska) [Sociocultural space of a modern Russian city (based on Krasnoyarsk city analysis)]. Krasnoyarsk. P. 128.

Shumov, K.Iu. (2002). Krasnoiarskie osobniaki V.A. Sokolovskogo [Krasnoyarsk mansions by V.A. Sokolovsky], In Surikovskie chteniia [Surikov readings], 46-48.

Sitnikova, A.A. (2014). Kontsept "sever" v tvorchestve Rokuella Kenta ["North" concept in works by Rockwell Kent], In Chelovek i kul'tura [Human and culture], 2, 1-27. DOI: 10.7256/23061618.2014.2.11550. Available at: http://e-notabene.ru/ca/article_11550.html

Sitnikova, A.A. (2015). K voprosu o metodologii issledovaniy kul'tury kak sotsial'noantropologicheskoy sistemy [To the question of methodology for studying culture as a socialanthropological system], In Sotsiodinamika [Sociodynamics], 1, 75-100. DOI: 10.7256/24097144.2015.1.14237. Available at: http://e-notabene.ru/pr/article_14237.html

Skinner, B.F. (1957). The verbal behaviour. N. Y.

Slabukha, A.V. (2004). Arkhitektory Prieniseyskoy Sibiri. Konets XIX-nachalo XXI veka

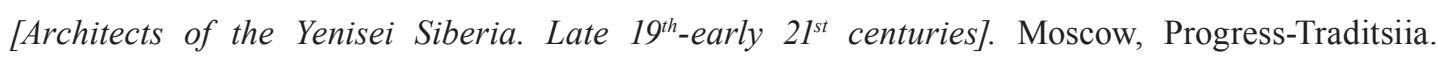
P. 432.

Smirnova, N.V. (2014). Genius loci: istoriko-kul'turnyy aspekt v proektirovanii [Genius loci: historical and cultural aspect of design], In Proceedings of the All-Russian scientific and practical conference "Modern tendencies in architectural design". Yekaterinburg.

Tarasova, M.V., Grigor'eva, T.Iu. (2015). Arkhitekturnyy dialog v prostranstve goroda Krasnoiarska [Architectural dialogue in the medium of Krasnoyarsk city], In Novaiia art-kritika na beregakh Eniseiia [New art criticism on the Yenisei banks]. Krasnoyarsk, 119-130. 
Tsariov, V.I. (2001). Krasnoiarsk. Istoriia i razvitie gradostroitel'stva [Krasnoyarsk. History and urban construction development]. Krasnoyarsk. P. 252.

Vseobschaia istoriia arkhitektury. Arkhitektura XIX-nachala XX vv. [Universal history of architecture. Architecture of the 19th-early $20^{\text {th }}$ centuries] (1972). Moscow, Stroyizdat. P. 591.

Zhukovskiy, V.I. (2004). Teoriia izobrazitel'nogo iskusstva [Visual art theory]. Krasnoyarsk.

Zhukovskiy, V.I., Koptseva, N.P. (2004). Propozitsii teorii izobrazitel'nogo iskusstva [Visual art theory propositions]. Krasnoyarsk.

Zhukovskiy, V.I., Koptseva, N.P. (2007). Znachenie zritelia v protsesse otnosheniia cheloveka i proizvedeniia izobrazitel'nogo iskusstva [Role of viewer in the process of relationships between the person and a piece of visual art], In Territoriia nauki [Science territory], 1, 95-102.

\title{
Специфика художественной культуры Красноярского края
}

\section{на материале анализа произведений искусства}

\section{Ю.Н. Авдеева, К.А. Дегтяренко,} А.А. Шпак

\author{
Сибирский федеральный университет
} Россия, 660041, Красноярск, пр. Свободный, 79

\begin{abstract}
Предметом исследования стало выявление региональных особенностей архитектуры для определения культурно-исторического значения архитектурных объектов конкретных регионов. На примере философско-искусствоведческого анализа дома Цукерман в городе Красноярске прослеживается то, как местная культура сохраняет исторически сложившиеся индивидуальные образы и вместе с тем видоизменяется под воздействием глобальной культуры. Данный факт удовлетворяет, с одной стороны, задачам культурной политики, связанным с сохранением объектов культурного наследия, а с другой-меняющиимся потребностям и образу жизни городского социума. Это свидетельствует о том, что региональное зодчество не изолировано от внешнего мира, оно принимает новые стилистические направления, актуальные для городского и соичокультурного пространства. Новизна исследования заключается в том, что в научный оборот вводятся эмпирические данные о художественно-эстетических качествах историко-культурной значимости публичных объектов зодчества в периферийных регионах России. Региональные объекты культурного наследия способны репрезентировать не только местные художественные и социикультурные явления, но и бщероссийские и мировые.
\end{abstract}

Ключевые слова: регионализм в архитектуре, региональная идентичность, контекстуализм, городское пространство, культурное пространство, городской соииум, эстетический портрет города, Красноярск, Дом Цукерман, «Дух места».

Исследование выполнено при поддержке краевого государственного автономного учреждения «Красноярский краевой фонд поддержки научной и научно-технической деятельности»в рамках реализации проекта: "Декоративно-прикладное искусство коренных малочисленных народов Красноярского края: современное состояние, перспективы развития».

Научная специильность: 24.00.00 - культурология. 